\title{
Molecular epidemiology of Hepatitis C virus genotypes in Khyber Pakhtoonkhaw of Pakistan
}

Amjad Ali $^{1}$, Habib Ahmed ${ }^{1 *}$, Muhammad Idrees $^{2}$

\begin{abstract}
Six major Hepatitis C virus (HCV) genotypes and hundreds of subtypes have been identified globally. All these genotypes are generally studied for epidemiology, their vaccine development and clinical management. This article comments the frequency distribution of various HCV genotypes circulate in different areas/districts of Khyber Pakhtoonkhaw Province of Pakistan. Sum of 415 HCV RNA PCR positive sera samples were tested by a molecular genotyping assay. Data analysis revealed that out of these 415 HCV RNA positive patients 243 were males and 172 were females. Distribution breakup of the patients was 135, 58, 51, 51, 36, 32, 6, 7and 9 patients come from the districts of Abbottabad, Mardan, Pehawar, Swat, Haripure, Swabi and Dera Ismail Khan, respectively. Out of the tested samples, genotype specific PCR fragments were observed in 299 (74.82\%) patient serum samples. The distribution of genotypes of the typeable samples was as fallows: 3 patients $(0.72 \%)$ each were infected with genotype 1 a and genotype 1 b; 240 patients (80.26\%) of genotype 3a; 25 patients (6.00\%) genotype 3b; and 28 patients (6.73\%) were observed as with mixed genotypic infection. Sums of 116 serum samples (27.88\%) were still found untypeable by the used molecular genotyping system.

In conclusion, HCV genotypes $1 \mathrm{a}, 1 \mathrm{~b}, 3 \mathrm{a}$ and $3 \mathrm{~b}$ are distributed in various parts of KPK among which the genotype $3 a$ is the most frequent genotype.
\end{abstract}

\section{Background}

Hepatitis $\mathrm{C}$ virus (HCV) infection is accountable for the second most common cause of viral hepatitis and is one of the most important Flaviviridae infections with significant clinical problems all over the globe in humans [1]. At least six major HCV genotypes and hundreds of subtypes have been identified worldwide so far [2]. Dissimilar HCV genotypes are related to epidemiological studies, response rates to anti-viral treatment, vaccine development and clinical management of the infection [3]. HCV genotype is the strongest foretelling factor for sustained virological response since patients with different $\mathrm{HCV}$ genotypes act in response differently to alpha interferon therapy $[4,5]$. Solid evidence has been established that HCV genotype- 2 and genotype- 3 infected patents are more likely to have a sustained virological response (SVR) to anti-viral therapy than patients infected with genotype-1 HCV infections [6]. The reported rates of SVR to interferon plus ribavirin

\footnotetext{
* Correspondence: habib@hu.edu.pk

'Deparment of Genetics, Hazara University, Garden Campus Mansehra Khyber Pakhtoonkhaw, Pakistan

Full list of author information is available at the end of the article
}

combination therapy are $65 \%$ and $30 \%$, in patients infected with $\mathrm{HCV}-2 / 3$ and $\mathrm{HCV}-1$ genotypes respectively $[7,8]$. As the patient genotype has a vital role in treatment outcome therefore, should be done before starting standard interferon therapy.

Three HCV genotypes such as HCV-1, HCV-2, and $\mathrm{HCV}-3$ have worldwide distribution and their relative prevalence varies from one geographic area to another. $\mathrm{HCV}-1 \mathrm{a}$ and $1 \mathrm{~b}$ subtypes are the most prevailing genotypes circulating in the United States of America and Europe [4,9-11]. In Japan the most common circulating HCV subtype is $1 \mathrm{~b}$ [12]. HCV-2a and $2 \mathrm{~b}$ subtypes are mostly common in North America, Europe, and Japan and subtype $2 \mathrm{c}$ is found commonly in northern Italy [9-12]. HCV-4 is the most prevalent genotype circulating in North Africa and the Middle East [13,14]. HCV-5 and HCV-6 genotypes are establish only in South Africa and Hong Kong, respectively [15,16].

A small number of studies are available from Pakistan on the distribution of different hepatitis $C$ virus genotypes only from the provinces of Punjab and Sindh [13,17-19]. No such study on the frequency distribution of various $\mathrm{HCV}$ genotypes and their modes of infectivity 
for different genotypes is available from Khyber Pakhtoonkhaw (KPK) of Pakistan. Therefore, this study was initiated to find out the molecular epidemiology of various HCV genotypes and subtypes present in KPK region of Pakistan and further to find out linked risk factors for its transmission.

\section{Methods \\ Sampling}

For the determination of HCV genotyping serum samples were collected along with specifically designed data sheets from patients admitted/attending various tertiary collection centers situated in different districts/parts of KPK, Pakistan. A written informed consent was taken from each patient. A printed data sheet was also filled for each patient contained demographic characteristic, possible mode of transmission, area/district, and estimated time of infection along with complete address and contact numbers of the patients.

\section{HCV RNA qualitative and quantitative PCRs}

HCV RNA was detected qualitatively using reverse transcriptase (RT) PCR as described before [17]. Briefly, total RNA was isolated from $150 \mu \mathrm{l}$ patient's sera samples using Gentra RNA isolation kit (Puregene, Minneapolis, MN 55441 USA) according to the kit protocol. Complimentary DNA (cDNA) of HCV 5 'NCR was synthesized using 100 units of Moloney murine leukemia virus (MMLV) reverse transcriptase enzyme (RTEs) (Invitrogen, Corp., California USA) with 5 pM of outer antisense primer. Two rounds of PCR amplifications were done (first round PCR and Nested PCR) with two unites of Taq DNA polymerase enzyme (Invitrogen, Corp., California USA) in a volume of $20 \mu$ l reaction mix. The nested PCR products were run on $2 \%$ agarose gel contained ethidium bromide as DNA stain. The specific HCV PCR bands were visualized under UV transilluminator.

HCV RNA was quantified in all qualitative PCR positive sera using SmartCycler II Real-time PCR (Cepheid, Sunnyvale, Calif. USA) utilizing HCV RNA quantification kits (Sacace Biotechnologies, Italy). The SmartCycler II system is a PCR system by which amplification and detection were accomplished concurrently with TaqMan technology (Applied Biosystems, Foster City, Calif) using fluorescent probes to detect amplification after each replicating cycle. The lower and upper detection limits of the used assay were $5.0 \times 10^{2}$ and $5.0 \times$ $10^{8} \mathrm{IU} / \mathrm{mL}$, respectively. Specimens yielding values above the upper limit were diluted 100 -fold, retested and the obtained values were multiplied by this dilution factor to get the actual HCV RNA concentration in international units per $\mathrm{mL}$.

\section{HCV Genotyping}

For all the samples HCV genotyping was carried out using molecular HCV genotyping method previously published by Idrees [20]. Briefly, $10 \mu \mathrm{l}$ (about $50 \mathrm{ng}$ ) of the extracted RNA was reverse transcribed to cDNA using $100 \mathrm{U}$ of M-MLV RTEs at $37^{\circ} \mathrm{C}$ for 50 minutes. The RTEs were killed at $96^{\circ} \mathrm{C}$ for 5 minutes. Two $\mu \mathrm{l}$ of cDNA was used for the amplification of 470-bp region from HCV 5 'NCR+Core region in first round PCR. Each first round PCR sample was subjected to two secondrounds nested PCR amplifications first with mix-A primers and the second with mix-B primers in a reaction volume of $20 \mu \mathrm{l}$. Mix-A had genotype-specific primers for $1 \mathrm{a}, 1 \mathrm{~b}, 1 \mathrm{c}, 3 \mathrm{a}, 3 \mathrm{c}$ and 4 genotypes and mix-B contained genotype-specific primers for $2 \mathrm{a}, 2 \mathrm{c}, 3 \mathrm{~b}, 5 \mathrm{a}$, and $6 \mathrm{a}$ genotypes. The second round PCR products were electrophoresed on a $2 \%$ agarose gel to separate typespecific PCR fragment. The gel was stained with ethidium bromide and was observed under UV transilluminator. A 100-bp DNA ladder (Invitrogen, Corp., California, USA) was run in each gel as DNA size marker and the HCV genotype for each sample was determined by identifying the HCV genotype-specific PCR band. The gel photograph was taken using gel documentation system (Geldoc System, Eppendorf Inc, Germany).

\section{Statistical analysis}

SPSS version 10.0 for windows was used for the analysis of data and summary statistics. The results for all variables were set in the form of rates (\%). Fisher's exact and Chi Square tests were applied to find out the positive association among the categorical variables. The data was obtainable as mean values or number of patients. P-value less than 0.05 was considered as significant.

\section{Results}

\section{Patients demographic}

Results regarding the demographic distribution of $\mathrm{HCV}$ patients genotyped are summarized in figure 1 . The figure also show enrolment and disposition criteria of the patients. The results revealed that out of total 663 anti$\mathrm{HCV}$ positive sera that were received from different districts of KPK province, 523 were found positive by HCV qualitative PCR where as 140 sera samples were found negative by PCR and were thus excluded from further evaluation. Viral load was determined on all the 523 HCV RNA positive samples. In 108 samples the viral load was less than $500 \mathrm{IU} / \mathrm{ml}$ that is sensitivity of the genotyping assay, therefore, these low titer sera samples were excluded from the study for further genotyping analysis as were below the sensitivity limits of the genotyping assay. The selected 415 sera samples with 


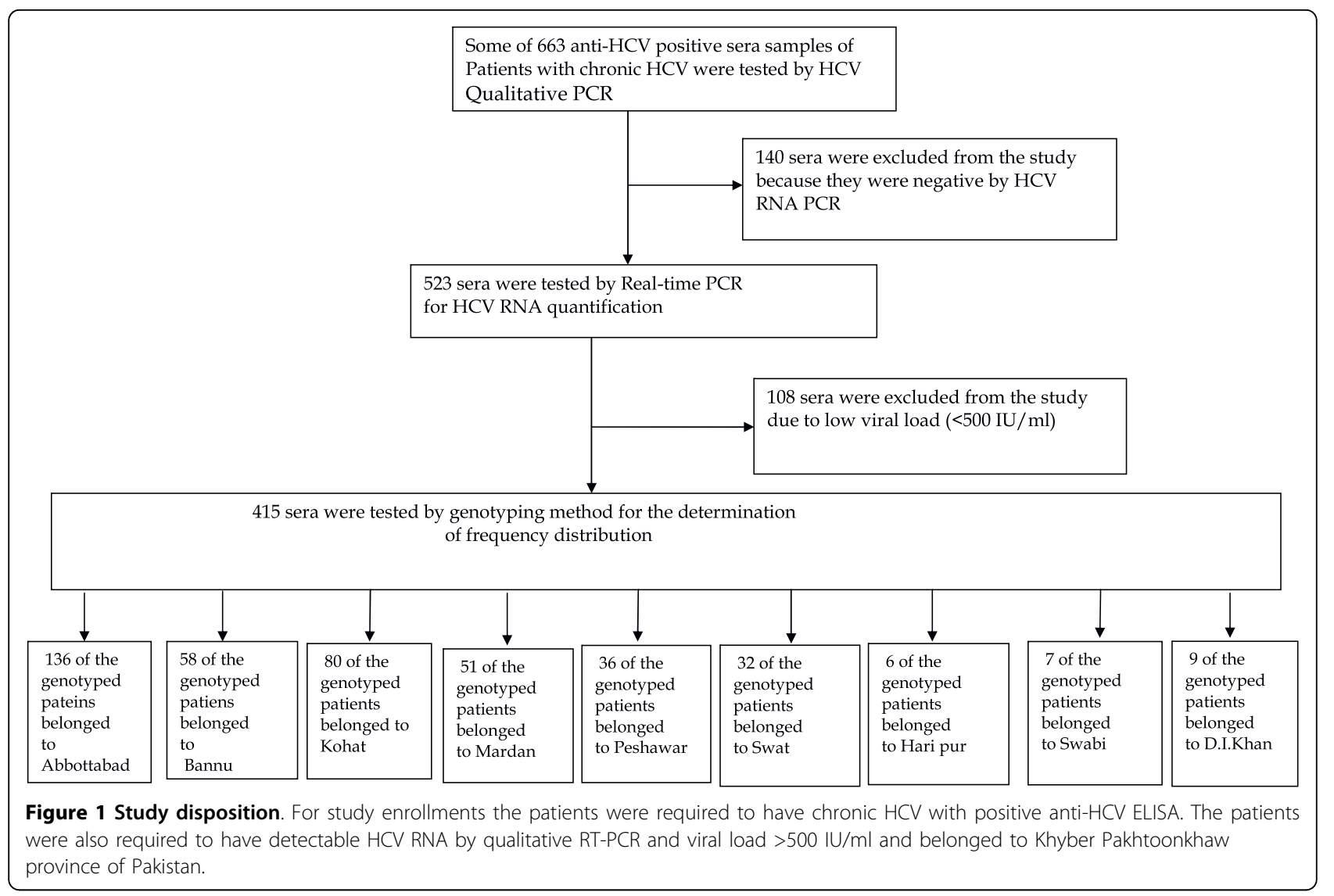

moderate to high viral load $\left(500-5.0 \times 10^{8} \mathrm{IU} / \mathrm{mL}\right.$ or above were tested by type-specific genotyping assay. The genotyped sera samples revealed that 136 belonged to Abbottabad region, 58 to Bannu, 80 to Kohat, 51 to Mardan, 36 to Peshawar, 32 to Swat, 6 to Haripur, 7 to Swabi and 9 patients came from D.I. khan. As all these serum samples that were included in the current study were tested HCV-RNA positive with enough viral load and could thus be genotyped by the utilized genotypespecific PCR assay. Figure-2 shows a typical agarose gel showing different $\mathrm{HCV}$ genotype-specific bands (HCV1a \& HCV-3a).

\section{Pattern of HCV genotypes in the study population}

The distribution of HCV genotypes in the population analyzed is given in the table 1 . The data shows that out of 415 tested sera samples, type-specific PCR fragments were seen in 299 (72.04\%) whereas $116(27.95 \%)$ sera samples were found untypable in the current study. The pattern of $\mathrm{HCV}$ genotypes of the typeable samples seen in the current study were in the order of: 240 (57.83\%) were genotype $3 \mathrm{a}, 25$ (6.02\%) were with genotype $3 \mathrm{~b}, 3$ $(0.72 \%)$ were $1 \mathrm{a}$ and $3(0.72 \%)$ were $1 \mathrm{~b}$. where as sum 28 $(6.73 \%)$ sera samples were infected with mixed genotype.

\section{Frequency distribution of HCV genotypes in different districts of KPK}

Frequency distribution of different $\mathrm{HCV}$ genotypes were recorded from individuals belonged to various districts of KPK is shown in table 2. Among the determined genotypes 136 patients were from Abbottabad. Among the genotyped samples from Abbottabad, 83 (61.02\%) belonged to genotype 3a, 5 (3.67\%) were genotype $3 \mathrm{~b}$, $11(8.08 \%)$ patients were infected by mixed genotype and $37(27.02 \%)$ patients were observed as of unknown genotype. From Bannu HCV positive cases were 58, among these 32 (55.17\%) were genotype $3 \mathrm{a}, 5$ (8.62\%) 3b, $3(5.17 \%)$ were of dual genotype i.e $3 a / 1 b$. Sum 18 (31.03\%) patients were of unknown genotype from District Bannu. Among 9 patients from D. I. Khan, 6 (66.66\%) belonged to 3a genotype, 3 (33.33\%) patients were observed as untypeable. Total 80 patients were positive to the corresponding virus from region of Kohat, $1(1.25 \%)$ patient each from $1 \mathrm{a}$ and $1 \mathrm{~b}$ genotype, 39 (48.75\%) were of 3a genotype, 2 (2.5\%) 3b genotype, mixed genotype was 6 (7.5\%). Patients having unknown HCV genotype were 31 (38.75\%). Among 51 Mardans patients $1 \mathrm{a}$ was $1(1.96 \%)$ and $1 \mathrm{~b}$ were $2(3.92 \%), 3 \mathrm{a}$ were $28(54.90 \%)$, 3b were 8 (15.68\%), 7 (13.72) were dual genotypes and $5(9.80)$ were untypeable genotypes. 


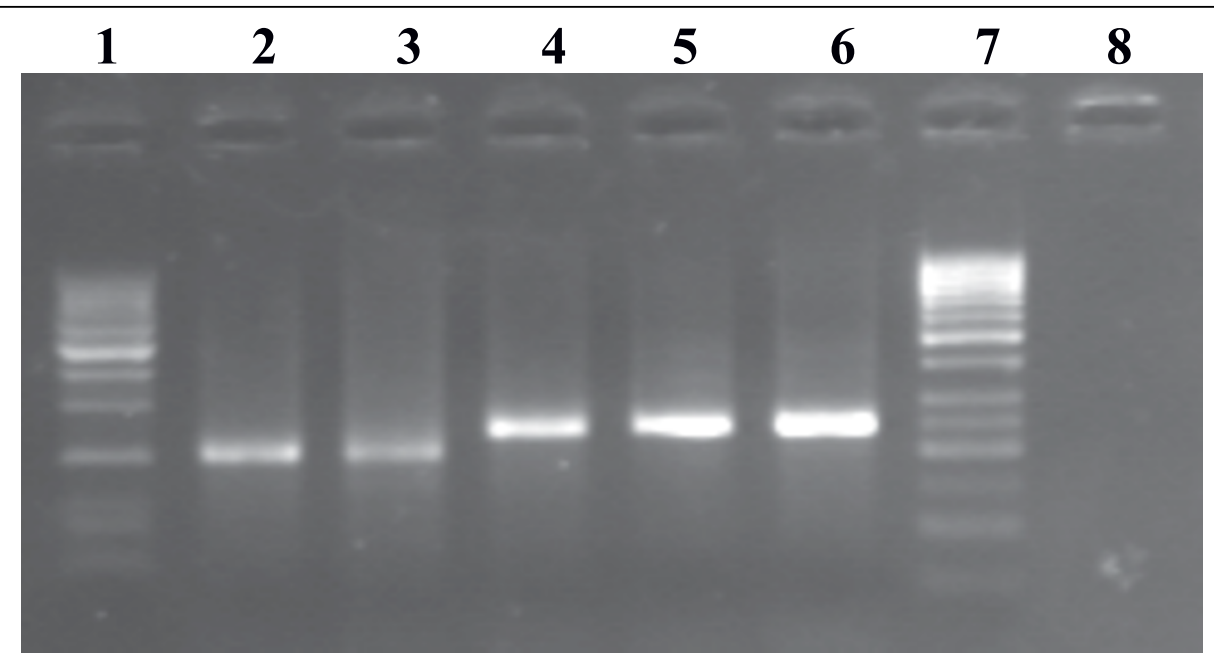

Figure 2 Typical agarose gel electrophoresis patterns of PCR products from two different HCV genotypes. Lanes 1 and 7 showing 50-bp DNA size ladder maker; Lanes 2-3 showed HCV-1a specific bands (210-bp); Lane 4-5 showed HCV-3a specific band (258-bp), Lane 6 showed Positive Control (258-bp HCV-3a genotype-specific band) and Lane 8 showed Negative Control (No band).

Of the 36 isolates from Peshawar city, 26 (72.22\%) were 3a, 3 (8.33\%) were $3 \mathrm{~b}, 7$ (19.44\%) were untypeable and none was observed as with dual genotype. Of the 32 positive sera samples isolated from district Swat, 1a genotype one (3.125\%) was of 1a genotype, $21(65.625 \%) 3 a$, 2 (6.25\%) 3b, mixed genotype 1 (3.125\%), 7 (19.44\%) were of untypeable genotype. From Haripur subtype 3a were present in $5(83.33 \%)$ patients and $1(16.66 \%)$ sample was found untypeable. All the 7 patients' sera collected from Swabi were found with untypeable genotypes.

\section{Occurrence of HCV with mixed genotypes}

Table 3 shows the prevalence of HCV mixed-genotype infections determined during the current study in different populations across KPK of Pakistan. Total $28 \mathrm{HCV}$ isolates were found having two genotypes. Of these, 11 belonged to Abbottabad region, 3 to Bannu district, 6 to Kohat district, 7 to Mardan district and only one to Swat district. Fourteen of the HCV infection with mixed genotypes had $\mathrm{HCV}$ genotypes $3 \mathrm{a}$ and $3 \mathrm{~b}$ followed by

Table 1 Frequency distribution of HCV genotypes and subtypes in the studied population $(N=415)$

\begin{tabular}{llll}
\hline HCV Genotype & HCV Subtype & No. of Isolates & Percentage \\
\hline 1 & $1 \mathrm{a}$ & 3 & 0.72 \\
& $1 \mathrm{~b}$ & 3 & 0.72 \\
3 & 3a & 240 & 57.83 \\
& 3b & 25 & 6.02 \\
Mixed & & 28 & 6.73 \\
Undetermined & & 116 & 27.95 \\
\hline Total & & 415 & 100 \\
\hline
\end{tabular}

$3 a+1 b$ that were $10(35.71 \%), 3 a+1 a$ in $3(10.71 \%)$ and $3 \mathrm{a}+2 \mathrm{~b}$ in 1 (3.57\%).

\section{Potential risk factors associated with the transmission of various genotypes}

Various possible risk factors observed in the current study responsible for infection transmission with each HCV genotypes are given in table 4. Over all the probable modes of spread observed were: $58.1 \%$ due to multiple uses of needles especially syringes, $16.7 \%$ due to surgeries (both major and minor), 3.3\% due to blood and blood products infectivity and in $23.1 \%$ patients the mode of spread was not known and therefore were sporadic. The foremost mode of contamination in patients with HCV genotype $3 \mathrm{a}$ and $3 \mathrm{~b}$ was multiple use and re-use of needles/syringes that was $70 \%$ and $60 \%$ respectively. All the genotype $1 \mathrm{a}$ and about $75 \% 1 \mathrm{~b}$ infected patients got their infection during surgeries. Sixty percent of the patients having dual infections were sporadic where the route of infectivity was unknown to them. Majority (58.1\%) of untypable patients were infected due to contaminated needles and syringes followed by surgeries and dental procedures.

\section{Discussion}

Khyber Pakhtoonkhaw (KPK) previously known as the North-West Frontier Province (NWP) is situated in the North-western of Pakistan and is one of the four provinces of Pakistan. It borders Gilgit-Baldistan to the north-east, Aghanistan to the north-west, the Federal Administrative Tribal Areas (FATA) to the west and south, Azad Jammu \& Kashmir to the east, Balochistan to the south and Punjab and the Islamabad Capital 
Table 2 Prevalence of HCV of comprise genotypes in different geographical regions of KPK of Pakistan

\begin{tabular}{|c|c|c|c|c|c|c|c|c|c|c|c|}
\hline Geno-type & $\begin{array}{l}\text { Sub- } \\
\text { type }\end{array}$ & $\begin{array}{l}\text { Isolated } \\
\text { from } \\
\text { Abbottabad }\end{array}$ & $\begin{array}{l}\text { Isolated } \\
\text { from } \\
\text { Bannu }\end{array}$ & $\begin{array}{l}\text { Isolated } \\
\text { from } \\
\text { Kohat }\end{array}$ & $\begin{array}{l}\text { Isolated } \\
\text { from } \\
\text { Mardan }\end{array}$ & $\begin{array}{l}\text { Isolated from } \\
\text { Peshawar }\end{array}$ & $\begin{array}{l}\text { Isolated } \\
\text { from } \\
\text { Swat }\end{array}$ & $\begin{array}{l}\text { Isolated } \\
\text { from Hari } \\
\text { pur }\end{array}$ & $\begin{array}{l}\text { Isolated } \\
\text { from } \\
\text { Swabi }\end{array}$ & $\begin{array}{l}\text { Isolated } \\
\text { from } \\
\text { D.I. } \\
\text { khan } \\
\end{array}$ & $\begin{array}{c}P \\
\text { value }\end{array}$ \\
\hline \multirow[t]{2}{*}{1} & $1 a$ & 0 & 0 & $1(1.25)$ & $1(1.96 \%)$ & 0 & $\begin{array}{l}1 \\
(3.125 \%)\end{array}$ & 0 & 0 & 0 & NS \\
\hline & $1 b$ & 0 & 0 & $1(1.25 \%)$ & 2 (3.92\%) & 0 & 0 & 0 & 0 & 0 & NS \\
\hline \multirow[t]{2}{*}{3} & $3 a$ & 83 (61.02\%) & $32(55.17 \%)$ & $\begin{array}{l}39 \\
(48.75 \%)\end{array}$ & $\begin{array}{l}28 \\
(54.90 \%)\end{array}$ & $26(2.22 \%)$ & $\begin{array}{l}21 \\
(65.625 \%)\end{array}$ & $5(3.33 \%)$ & 0 & $6(6.66 \%)$ & $<0.05$ \\
\hline & $3 b$ & 5 (3.67\%) & $5(8.62 \%)$ & $2(2.5 \%)$ & $\begin{array}{l}8 \\
(15.68 \%)\end{array}$ & $3(8.33 \%)$ & $2(6.25 \%)$ & 0 & 0 & 0 & $<0.05$ \\
\hline Mixed & & $11(8.08 \%)$ & $3(5.17 \%)$ & $6(7.5 \%)$ & $\begin{array}{l}7 \\
(13.72 \%)\end{array}$ & 0 & $\begin{array}{l}1 \\
(3.125 \%)\end{array}$ & 0 & 0 & 0 & NS \\
\hline Undetermined & & 37 (27.20\%) & $18(31.03 \%)$ & $\begin{array}{l}31 \\
(38.75 \%)\end{array}$ & $5(9.80 \%)$ & 7 (19.44\%) & $\begin{array}{l}7 \\
(21.375 \%)\end{array}$ & $1(6.66 \%)$ & 7 (100\%) & $3(3.33 \%)$ & $>0.05$ \\
\hline$\overline{T o t a l}$ & & 136 & 58 & 80 & 51 & 36 & 32 & 6 & 7 & 9 & \\
\hline
\end{tabular}

Territory to the south-east. KPK is the third most populous province of the country. The main ethnic group in the province is Pakhtuns, followed by a number of smaller ethnic groups most notably, the Hindkowans; therefore, in the current study we tried to determine the pattern of HCV genotype in this specific ethnic groupPakhtuns. A recently published genotype-specific PCRbased method [20] with increased sensitivity and specificity was employed for HCV genotypes determination. The data presented here corresponds to the preceding studies, in which genotypes, sub-types and/or serotypes were determined [9,21-23]. Analysis of the data showed that genotype $3 \mathrm{a}$ is the predominant genotype circulating in patients with chronic hepatitis $\mathrm{C}$. These findings verified results of the earlier studies from Pakistan [17-19] which have concluded that genotype $3 a$ is the most prevalent HCV genotype in Pakistan. Similarly in India, the predominant HCV genotype is $3 a[24,25]$. Our finding regarding distribution of the genotype seems to be similar to the genotype pattern reported from other Far Asian country such as Nepal [26] but different from those in South Asian countries such as Japan [27], Thailand [28] and Vietnam where genotype 1 is the major HCV genotype circulating in their populations.

Our study led to several important findings. The first finding is incidence of $\mathrm{HCV}$ genotypes that confirms the findings of another study from this country [23]. The second important finding of the study was the isolation of $27 \%$ isolates that were undetermined as no genotypespecific PCR products were seen for these samples. All these 116 sera samples with indetermined genotypes were $\mathrm{HCV}$-RNA positive by qualitative PCR and were with sufficient viral titer therefore might be genotyped by the utilized genotype-specific PCR assay. A recent study from other parts of Pakistan showed only 6\% HCV infected sera samples with untypable genotypes by this molecular biology-based system [23]. The high rate of untypable results seen in the current study may be due to the reason that majority (more than eighty percent) of our untypable patients had received standard interferon plus ribavirin treatment in the past and were either non-responders or were relapsed thereafter. Why the previously treated patients are difficult to genotype with higher sensitivity using this molecular based genotyping assay is not known to us.

We were unable to isolate even a single HCV-4 genotype from any infected patient that is believed to be absent from Pakistan, and is the most prevalent $\mathrm{HCV}$ genotype in Middle East [13]. None of the patients of the current study was found infected by genotype $5 \mathrm{a}$ and 6a. The two genotypes are reported from South Africa and Hong Kong, respectively $[15,16]$ and may be absent or very rare in this part of the world.

Table 3 Prevalence of HCV mixed genotypes in KPK, Pakistan

\begin{tabular}{|c|c|c|c|c|c|c|c|c|c|c|}
\hline $\begin{array}{l}\text { Mixed } \\
\text { genotype }\end{array}$ & $\begin{array}{l}\text { From } \\
\text { Abbottabad }\end{array}$ & $\begin{array}{l}\text { From } \\
\text { Bannu }\end{array}$ & $\begin{array}{l}\text { From } \\
\text { DIK }\end{array}$ & $\begin{array}{l}\text { From } \\
\text { Kohat }\end{array}$ & $\begin{array}{l}\text { From } \\
\text { Mardan }\end{array}$ & $\begin{array}{l}\text { From } \\
\text { Peshawar }\end{array}$ & $\begin{array}{l}\text { From } \\
\text { Swat }\end{array}$ & $\begin{array}{l}\text { From } \\
\text { Haripur }\end{array}$ & $\begin{array}{l}\text { From } \\
\text { Swabi }\end{array}$ & $\mathrm{N}$ \\
\hline $3 a+3 b$ & 8 & 0 & 0 & 4 & 2 & 0 & 0 & 0 & 0 & 14 \\
\hline $3 a+1 a$ & 2 & 0 & 0 & 0 & 0 & 0 & 1 & 0 & 0 & 3 \\
\hline $3 a+1 b$ & 0 & 3 & 0 & 2 & 5 & 0 & 0 & 0 & 0 & 10 \\
\hline $3 a+2 b$ & 1 & 0 & 0 & 0 & 0 & 0 & 0 & 0 & 0 & 1 \\
\hline Total & 11 & 3 & 0 & 6 & 7 & 0 & 1 & 0 & 0 & 28 \\
\hline
\end{tabular}


Table 4 Potential routes of transmission of various HCV genotypes

\begin{tabular}{lllll}
\hline HCV & Possible routes of transmission & & & Blood Transfusion (\%) \\
\hline $\begin{array}{l}\text { HCV } \\
\text { subtypes(N) }\end{array}$ & Re use of needles syringes (\%) & Surgery, dentil operation (\%) & $\begin{array}{l}\text { Unclassified } \\
\text { (\%) }\end{array}$ \\
\hline $1 \mathrm{a}(3)$ & 0 & $3(100)$ & 0 & 0 \\
$1 \mathrm{~b}(3)$ & 0 & $2(75)$ & 0 & $1(25)$ \\
$3 \mathrm{a}(240)$ & $168(70)$ & $33(13.8)$ & $6(2.5)$ & $33(13.8)$ \\
$3 \mathrm{~b}(25)$ & $15(60)$ & $7(28)$ & 0 & $3(12)$ \\
Mixed (28) & $5(17.9)$ & $4(14.3)$ & $02(7.1)$ & $17(60.7)$ \\
Undetermined (116) & $53(45.7)$ & $21(18.1)$ & 0 & $42(36.2)$ \\
\hline Total (415) & $\mathbf{2 4 1 ( 5 8 . 1 )}$ & $\mathbf{7 0 ( 1 6 . 7 )}$ & $\mathbf{0 8 ( 1 . 9 )}$ & $\mathbf{9 6}(\mathbf{2 3 . 1 3})$ \\
\hline
\end{tabular}

The distribution of HCV genotypes for this population was examined district wise in order to establish a base line for regional differences in HCV pattern in KPK. No regional difference with respect to $\mathrm{HCV}$ genotype distribution in all districts was observed where the most prevalent genotype is 3a. However, a difference was observed in district Swabi where all the isolates were found untypeable. All these isolates had high titer of HCV RNA and could thus be genotyped however; majority of these patients had a history of interferon treatment.

In the current study sum 28 isolates of HCV patients had two genotypes at a time in their blood. Majority of these (39\%) were the residents of district Abbottabad region where blood transfusion is common in thalassaemic patients. More than half of our patients with dual infection had HCV genotypes $3 \mathrm{a}$ and $3 \mathrm{~b}$. Like other studies, the prevalence of HCV mixed-genotype infections was high in thalassaemic patients who had received multiple blood transfusions. The overall rate of $\mathrm{HCV}$ mixedgenotype infections was $6.7 \%$, which is the same as reported recently by Idrees and Riazuddin [23] from other provinces of the country.

It has been recognized in the current study that different HCV genotypes might be associated with different transmission routes. For example genotype 3a appears to be prevalent among injection drug users and dual infection among thalassaemic patients who had received blood transfusion several times in life. It is believed that HCV-3a was introduced into North America and the United Kingdom with the widespread use of heroin in the 1960s [29]. For more than $58 \%$ of our patients the probable modes of transmission observed were multiple uses and re-uses of needles/syringes. In $16.7 \%$ patients it was due to surgeries (both major and minor), 3.3\% due to blood and blood products contamination and in $23.1 \%$ patients the mode of contamination was not known and was sporadic. The dominant mode of contamination in patients with $\mathrm{HCV}$ genotype $3 \mathrm{a}$ and $3 \mathrm{~b}$ was multiple and re-use of needles/syringes that was $70 \%$ and $60 \%$ respectively. All the genotype $1 \mathrm{a}$ and $75 \%$
$1 \mathrm{~b}$ infected patients got their infection during surgeries. Sixty percent of the patients having dual infections were sporadic where the route of contamination was unknown to them. Majority (58.1\%) of untypable patients were infected by contaminated needles and syringes followed by surgeries and dental procedures. In Pakistan HCV-3a is the most widespread genotype as been also observed in the current study. It is believed that this genotype is spread by medical practitioners like doctors, vaccination teams and other medical persons used non-disposable syringes for injections attended a number of patients in the past. Mass vaccination in the recent past in which un-sterilized syringes were used might have enhanced the infection rate in this country [23]. This type of practice is still common in the countryside especially in KPK province which needs effective check for minimizing the spread of $\mathrm{HCV}$ infection and the transmission of other communicable diseases.

The only limitation of this study is the detection of large number $(27 \%)$ of samples with untypable genotypes. All these samples were HCV-RNA positive, had sufficient viral titer and therefore might be genotyped by sequencing method to designate the exact genotype, however, we were unable to sequence these samples due to lack of sequencing facility in our campus.

\section{Conclusion}

We conclude that (i) HCV genotypes 1a, 1b, 3a and 3b are distributed in various parts of KPK (ii) genotype $3 \mathrm{a}$ is the most frequent genotype circulating in KPK (iii) Major mode of HCV transmission is multiple uses and re-uses of needles/syringes.

\section{Abbreviations}

HCV: hepatitis C virus; M-MLV: Molony-murine leukemia virus; NWFP: North West frontier province; KPK: Khyber Pakhtoonkhaw; ABI: Applied Biosystem Inc.; RT-PCR: reverse transcriptase polymerase chain reaction; cDNA: complimentary DNA.

\section{Author details}

${ }^{1}$ Deparment of Genetics, Hazara University, Garden Campus Mansehra Khyber Pakhtoonkhaw, Pakistan. ${ }^{2}$ Division of Molecular Virology, National 
Centre of Excellence in Molecular Biology, 87-West Canal Bank Road Thokar Niaz Baig Lahore-53700, University of the Punjab Lahore, Pakistan.

\section{Authors' contributions}

HA conceived the study, participated in its design and coordination and gave a critical view of manuscript writing. AA collected epidemiological data, performed genotype analysis and analyzed the data statistically. MI helped AA in molecular genotyping assays and gave a critical view of manuscript writing and participated in data analysis. All the authors read and approved the final manuscript.

\section{Competing interests}

The authors declare that they have no competing interests.

Received: 2 August 2010 Accepted: 26 August 2010

Published: 26 August 2010

\section{References}

1. Leiveven J, Pegasys RBV: Improves Fibrosis in Responders, relapsers \& Nonresponders with Advanced Fibrosis. 55th Annual Meeting of the American Association for the Study of Liver Disease: 2004 October 29November 2 Boston, MA, USA.

2. Zein NN, Persing $\mathrm{DH}$ : Hepatitis $C$ Genotypes: current trends and future implications. Mayo Clin Proc 1996, 71:458-462

3. Liew M, Erali M, Page S, Hillyard D, Wittwer C: Hepatitis C Genotyping by Denaturing High-Performance Liquid Chromatography. J Clin Microbiol 2004, 42(1):158-163.

4. Zein NN, Rakela J, Krawitt EL, Reddy KR, Tominaga T, Persing DH: Hepatitis $C$ virus genotypes in the United States: epidemiology, pathogenicity, and response to interferon therapy. Ann Intern Med 1996, 125:634-639.

5. Trepo C: Seminar on hepatitis C. European Commission Public Health Unit 1994.

6. Dusheiko G, Schmilovitz H, Brown D, McOmish F, Yap PL, Simmonds P: Hepatitis $C$ virus genotypes: an investigation of type-specific differences in geographic origin and disease. Hepatology 1996, 19:13-18.

7. McHutchison JG, Gordon SC, Schiff ER, Shiffman ML, Lee WM, Rustgi VK, Goodman ZD: Interferon alfa-2b alone or in combination with ribavirin as initial treatment for chronic hepatitis C. Hepatitis Interventional Therapy Group. N Engl J Med 1998, 339:1485-1492.

8. Poynard T, Marcellin P, Lee SS, Niederau C, Minuk GS, Ideo G, Bain V, Heathcote J, Zeuzem S, Trepo C, Albrecht J: Randomized trial of interferon alpha2b plus ribavirin for 48 weeks or for 24 weeks versus interferon alpha2b plus placebo for 48 weeks for treatment of chronic infection with hepatitis $C$ virus. International Hepatitis Interventional Therapy Group (IHIT). Lancet 1998, 352:1426-1432.

9. McOmish F, Yap PIL, Dow BC, Follett EAC, Seed C, Keller AJ, Cobain TJ, Krusius T, Kolho E, Naukkarinen R, Lin C, Lai C, Leong S, Medgyesi GA, He'jjas M, Kiyokawa H, Fukada K, Cuypers T, Saeed AA, Al-Rasheed AM, Lin $M$, Simmonds P: Geographic distribution of hepatitis $C$ virus genotypes in blood donors: an international collaborative survey. $J$ Clin Microbiol 1994, 32:884-92.

10. Dusheiko G, Main J, Thomas H: Ribavirin treatment for patients with chronic hepatitis C: results of a placebo-controlled study. J Hepatol 1994 25(5):591-8.

11. Nousbaum JB, Pol $S$, Nalpas B, Landais $P$, Berthelot $P$, Brechot $C$, the Collaborative Study Group: Hepatitis $C$ virus type $1 \mathrm{~b}$ (II) infection in France and Italy. Ann Intern Med 1995, 122:161-168.

12. Takada NS, Takase S, Takada A, Date T: Differences in the hepatitis C virus genotypes in different countries. J Hepatol 1993, 17:277-283.

13. Abdulkarim AS, Zein NN, Germer JJ, Kolbert CP, Kabbani L, Krajnik KL, Hola A, Agha MN, Tourogman M, Persing DH: Hepatitis C virus genotypes and hepatitis $G$ virus in hemodialysis patients from Syria: identification of two novel hepatitis C virus subtypes. Am J Trop Med Hyg 1998, 59:571-576.

14. Chamberlain RW, Adams N, Saeed AA, Simmonds P, Elliot RM: Complete nucleotide sequence of a type 4 hepatitis $C$ virus variant, the predominantgenotype in the Middle East. J Gen Virol 1997, 78:1341-1347.

15. Simmonds P, Holmes EC, Cha TA, Chan SW, McOmish F, Irvine B, Beall E, Yap PL, Kolberg J, Urdea MS: Classification of hepatitis $C$ virus into six major genotypes and a series of subtypes by phylogenetic analysis of the NS-5 region. J Gen Virol 1993, 74:2391-9.
16. Cha TA, Kolberg J, Irvine B, Stempien M, Beall E, Yano M, Choo QL, Houghton M, Kuo G, Han JH, Urdea MS: Use of a signature nucleotide sequence of hepatitis $C$ virus for detection of viral RNA in human serum and plasma. J Clin Microbiol 1992, 29:2528-2534.

17. Idrees $\mathrm{M}$ : Common genotypes of hepatitis $\mathrm{C}$ virus present in Pakistan. Pak J Med Res 2001, 40:(2): 46-49.

18. Shah HA, Jafri WS, Malik I, Prescott L, Simmonds P: Hepatitis C virus (HCV) genotypes and chronic liver disease in Pakistan. $J$ Gastroenterol Hepatol 1997, 12:758-761

19. Idrees M: Detection of Six Serotypes of HCV in anti-HCV Positive Patients and rate of ALT/AST abnormalities. Pak J Microbiol 2001, 2:61-65.

20. Idrees M: Development of an improved HCV Genotyping Assay for the Detection of Common Genotypes and subtypes in Pakistan. J Virol Meth 2008, 150(1):50-56

21. Jarvis LM, Ludlam CA, Ellender JA, Nemes L, Field SP, Song E, Chuansumrit $A$, Preston FE, Simmonds $P$ : Investigation of the relative infectivity and pathogenicity of different hepatitis $C$ virus genotypes in hemophiliacs. Blood 1996, 87:3007-11.

22. Pa'r A, Gervain J, Go'gl A: Hepatitis C virus infection: pathogenesis, diagnosis and treatment. Scand J Gastroenterol Supp/ 1998, 228:107-14.

23. Idrees $M$, Riazuddin S: Frequency Distribution of Hepatitis C Virus Genotypes in Different Geographical Regions of Pakistan and their Possible Routes of Transmission. BMC Infectious Diseases 2008, 8:69.

24. Chowdhury A, Santra A, Chaudhuri S, Dhali GK, Chaudhuri S, Maity SG, Naik TN, Bhattacharya SK, Mazumder DN: Hepatitis $C$ virus infection in the general population: a community-based study in west Bengal, India. Hepatology 2003, 37(4):802-9.

25. Singh $B$, Verma $M$, Verma K: Markers for transfusion-associated hepatitis in north Indian blood donors: prevalence and trends. Jpn J Infect Dis 2004, 57(2):49-51.

26. Tokita H, Shrestha SM, Okamoto H, Sakamoto M, Horikita M, lizuka H, Shrestha S, Miyakawa Y, Mayumi M: Hepatitis C virus variants from Nepal with novel genotypes and their classification into the third major group. J Gen Virol 1994, 75:931-936.

27. Shinji T, Kyaw Y, Gokan K, Tanaka Y, Ochi K: Analysis of HCV genotypes from blood donors shows three new HCV types 6 subgroups exist in Myanmar. Acta Med Okayama 2004, 58(3):135-42.

28. Tokita $\mathrm{H}$, Okamoto $\mathrm{H}$, Luengrojanakul $\mathrm{P}$, Vareesangthip $\mathrm{K}$, Chainuvati $\mathrm{T}$, lizuka H, Tsuda F, Miyakawa Y, Mayumi M: Hepatitis $C$ virus variants from Thailand classifiable into five novel genotypes in the sixth (6b), seventh (7c, 7d) and ninth (9b, 9c) major genetic groups. J Gen Virol 1995, 76:2329-2335.

29. Pawlotsky JM, Dussaix E, Simmonds P, Prescott L, Pellet C, Lau-rent-Puig P, Labonne C, Remire J, Darthuy F, Duval J, Buffet C, Etienne JP, Dhumeaux D: Hepatitis $C$ virus (HCV) genotype determination: genotyping versus serotyping. Hepatology 1995, 22:359A

doi:10.1186/1743-422X-7-203

Cite this article as: Ali et al:: Molecular epidemiology of Hepatitis C virus genotypes in Khyber Pakhtoonkhaw of Pakistan. Virology Journal 2010 7:203.

\section{Submit your next manuscript to BioMed Central and take full advantage of:}

- Convenient online submission

- Thorough peer review

- No space constraints or color figure charges

- Immediate publication on acceptance

- Inclusion in PubMed, CAS, Scopus and Google Scholar

- Research which is freely available for redistribution 